\title{
Biosorption of Hexavalent Chromium Metal Ions by Lentinula Edodes Biomass: Kinetic, Isothermal, and Thermodynamic Parameters
}

\author{
Aslı Göçenoğlu Sarıkaya* \\ * Bursa Uludag University, Faculty of Art and Science, Department of Chemistry, Görükle Campus, Turkey, \\ *Corresponding author: E-mail: agocenoglu@uludag.edu.tr \\ +902242942867
}

Received: 09-23-2020

\begin{abstract}
Lentinula edodes was investigated as a biosorbent for hexavalent chromium biosorption in this study. To examine the optimum conditions of biosorption, the $\mathrm{pH}$ of the hexavalent chromium solution, biosorbent dosage, temperature, contact time, and initial hexavalent chromium concentration were identified. Further, to clarify the biosorption mechanism process, the isothermal, kinetic, and thermodynamic parameters were determined. The functional groups and surface morphology of the biosorbent were identified using Fourier transform infrared spectrometry and scanning electron microscopy in the absence and presence of hexavalent chromium, respectively. Based on the results, the maximum biosorption capacity was determined as $194.57 \mathrm{mg} \mathrm{g}^{-1}$ under acidic conditions at $45^{\circ} \mathrm{C}$. From the kinetics studies, the biosorption process was observed to follow the Freundlich isotherm and pseudo-second-order kinetic models well. Thus, L. edodes as a biosorbent has potential usage for wastewater treatment owing to its effective biosorption capacity.
\end{abstract}

Keywords: Biosorption, fungal biosorbent, hexavalent chromium, Lentinula edodes.

\section{Introduction}

Pollution by heavy metal impurities is one of the major problems of increasing industrial development. ${ }^{1,2}$ Chromium is one of the common pollutants in nature and exists in different oxidation states $(-2$ to +6$)$ in the environment; however, trivalent chromium $\left(\mathrm{Cr}^{3+}\right)$ and hexavalent chromium $\left(\mathrm{Cr}^{6+}\right)$ forms tend to be the most available and stable oxidation states in water. ${ }^{3}$ The hexavalent form of chromium is more toxic than the trivalent form and is known as a carcinogenic that causes liver damage, congestion in the lungs, changes to the genetic code, and skin irritation. ${ }^{4-6}$ The most common sources of hexavalent chromium wastes are industrial sectors such as textiles, metal finishing, leather tanning, electroplating, cement, and steel. ${ }^{7,8}$

The traditional processes used to remove hexavalent chromium are electrochemical reduction, solvent extraction, electro dialysis, ion exchange, reverse osmosis, and chemical precipitation. Owing to disadvantages such as high cost and increased time consumption of these methods, new procedures have been developed. Biosorption is one of the alternative methods for wastewater treatment and is widely used in batch and continuous studies because of its advantages such as low cost, reusability, and easy operation, which are attractive benefits. ${ }^{9,10}$ Shells, ${ }^{11}$ leaves, ${ }^{12}$ fungi, ${ }^{9}$ bacteria, ${ }^{13}$ and yeast ${ }^{14}$ have been previously reported as biosorbents for hexavalent chromium biosorption.

Lentinula edodes ranks second in the global mushroom market and is commonly known as "shiitake mushroom"15 it is- the most popular edible mushroom in Japan and China-, and its nutritional components enable $L$. edodes to be used as traditional medicinal mushrooms in eastern Asia. It grows in the deciduous forests of Asia under warm and humid climatic conditions. The goal of this study is to verify removal of hexavalent chromium from water using $L$. edodes as a biosorbent. The effects of different parameters on the biosorption process, reusability of the biosorbent, and some physicochemical parameters are optimized in this study.

\section{Materials and Methods}

\section{1. L. edodes Biosorbent Preparation}

L. edodes was obtained from a commercial market in Izmir (Turkey), washed twice with deionized water, and 
dehydrated at $30{ }^{\circ} \mathrm{C}$. The dried fungus was then crushed with a grinder after cutting into small pieces. The biosorbent powder (90-120 $\mu \mathrm{m}$ size) was subsequently stored in a glass jar for biosorption studies.

\section{2. Batch Biosorption Experiments}

The stock solution of hexavalent chromium (1000 mg $\mathrm{L}^{-1}$ ) was prepared by dissolving $\mathrm{K}_{2} \mathrm{Cr}_{2} \mathrm{O}_{7}$ (Sigma-Aldrich) in pure water and diluting in the range of $10-1000 \mathrm{mg} \mathrm{L}^{-1}$. Approximately $0.01 \mathrm{~g}$ of the L. edodes biosorbent was used in the biosorption processes with $25 \mathrm{~mL}$ total volume of known hexavalent chromium solutions. To obtain the optimum $\mathrm{pH}$ in the range of 2-6, the solution was maintained using $0.1 \mathrm{~mol} \mathrm{~L}^{-1} \mathrm{NaOH}$ and $0.1 \mathrm{~mol} \mathrm{~L}^{-1} \mathrm{HCl}$. The impact of temperature was examined via experiments performed at 4,25 , and $45^{\circ} \mathrm{C}$. To optimize the contact time, the biosorption process was conducted for 10-180 $\mathrm{min}$. The biosorbent was removed from the solution before analyzing the remaining hexavalent chromium solution via centrifugation for $10 \mathrm{~min}$ at $5000 \mathrm{rpm}$, and the supernatant was analyzed according to the 1,5-diphenylcarbazide spectrophotometric method at $540 \mathrm{~nm}$ (Perkin Elmer Lambda 35 UV/Vis Spectrometer).

The hexavalent chromium concentration at equilibrium can be determined according to Eq. 1 as follows:

$$
q_{e}=\frac{\left(C_{0}-C_{e}\right)}{m} V
$$

where $q_{e}$ is the amount of absorbed hexavalent chromium ions $\left(\mathrm{mg} \mathrm{g}^{-1}\right), C_{o}$ and $C_{e}$ are the initial and final concentrations of hexavalent chromium $\left(\mathrm{mg} \mathrm{L}^{-1}\right), V$ is the total solution volume $(\mathrm{mL})$, and $m$ is the mass of the biosorbent $(\mathrm{g})$.

Desorption percentages were calculated with $0.1 \mathrm{~mol}$ $\mathrm{L}^{-1} \mathrm{HNO}_{3}$ and $0.1 \mathrm{~mol} \mathrm{~L}^{-1} \mathrm{HCl}$ using the following equation:

$$
\% \text { Desorption }=\frac{C_{\text {des }}}{C_{\text {ads }}} \times 100
$$

where $C_{d e s}$ is the amount of hexavalent chromium ions desorbed on the desorption medium and $C_{a d s}$ is the amount of hexavalent chromium ions adsorbed onto the biosorbent. The adsorbed biosorbents were shaken at $200 \mathrm{rpm}$ on a magnetic shaker at $25^{\circ} \mathrm{C}$ for $24 \mathrm{~h}$.

\section{3. Characterization of Biomass}

Fourier transform infrared (FTIR) spectroscopy (Perkin Elmer Spectrum BX FTIR System) and scanning electron microscopy (SEM, ZEISS EVO 40) were used to identify the binding sites and functional groups on the fungal biosorbent surface as weel as the surface morphology of the biosorbent in the absence and presence of hexavalent chromium, respectively.

\section{Results and Discussion}

\section{1. Effects of $\mathbf{p H}$}

The $\mathrm{pH}$ of an aqueous solution is a crucial factor for the biosorption process and affects the ion sorption efficiency. The charges of the functional groups of the biosorbent and distribution of the hexavalent chromium species are affected by changes in the solution $\mathrm{pH}$. Therefore, the biosorption and reduction processes have different affinities. ${ }^{16}$ The maximum biosorption capacity $\left(q_{e}\right)$ of hexavalent chromium on the L. edodes biosorbent was determined as $6.12 \mathrm{mg} \mathrm{g}^{-1}$ at a $\mathrm{pH}$ of 2.0 (Figure 1).

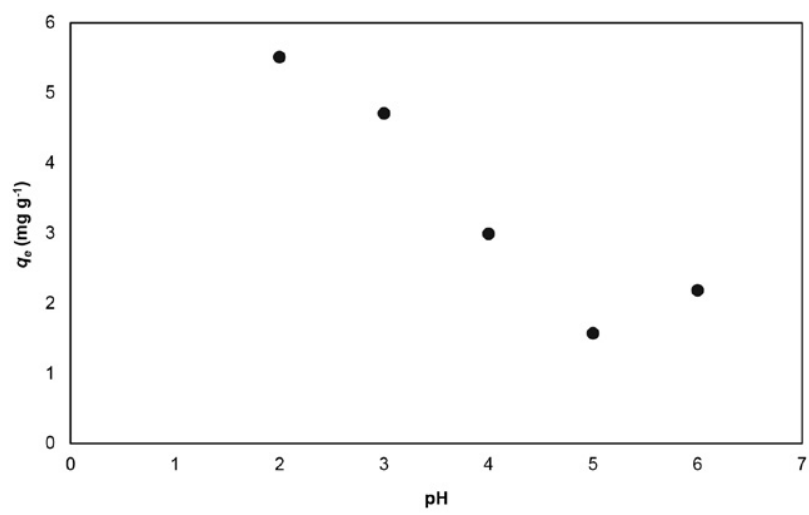

Figure 1. Effect of $\mathrm{pH}$ on hexavalent chromium biosorption capacity $\left(q_{e}\right)$ onto $L$. edodes biosorbent.

The experiments were performed for $120 \mathrm{~min}$ at 25 ${ }^{\circ} \mathrm{C}$ with $10 \mathrm{mg} \mathrm{L}^{-1}$ as the initial hexavalent chromium concentration, hence, the suitable $\mathrm{pH}$ was chosen as 2.0 for biosorption. Generally, in aqueous hexavalent chromium solutions, $\mathrm{HCrO}_{4}^{-}, \mathrm{Cr}_{2} \mathrm{O}_{7}{ }^{2-}, \mathrm{CrO}_{4}{ }^{2-}$, and $\mathrm{H}_{2} \mathrm{CrO}_{4}$ are the dominant species. ${ }^{17}$ Under acidic condition $(\mathrm{pH}$ $\leq 4.0) \mathrm{HCrO}_{4}^{-}, \mathrm{Cr}_{2} \mathrm{O}_{7}{ }^{2-}$, and $\mathrm{H}_{2} \mathrm{CrO}_{4}$ are the main forms of hexavalent chromium. $\mathrm{HCrO}_{4}{ }^{-}$is the dominant form of hexavalent chromium at a $\mathrm{pH}$ of 2.0. ${ }^{18}$ Owing to protonation of the amino functional groups, the cell surface become positively charged, hence, the acid chromate can perfectly interact with the protonated biomass surface. $^{3,19}$

\section{2. Effects of Biosorbent Dosage}

To examine the effects of biosorbent dosage on hexavalent chromium biosorption, different amounts of the biosorbent were tested in the range of $0.025-0.200 \mathrm{~g}$. Approximately $100 \mathrm{mg} \mathrm{mL}^{-1}$ of the initial hexavalent chromium concentration and $25 \mathrm{~mL}$ of total volume of the ion solutions were used at $25^{\circ} \mathrm{C}$. As the biosorbent dosage increased from $0.025 \mathrm{~g}$ to $0.200 \mathrm{~g}$, the $q_{e}$ value decreased from $24.46 \mathrm{mg} \mathrm{g}^{-1}$ to $3.94 \mathrm{mg} \mathrm{g}^{-1}$ (Figure 2). As the total amount of hexavalent chromium biosorbed on the biosorbent increases, the $q_{e}$ per unit of biomass reduces because of the fixed concentration. ${ }^{20}$ 


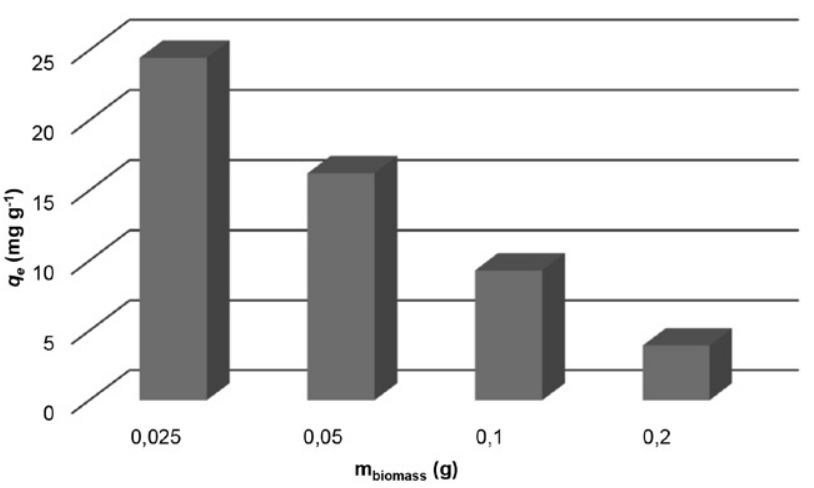

Figure 2. Effect of biosorbent dosage on hexavalent chromium biosorption capacity $\left(q_{e}\right)$ onto the L. edodes biosorbent.

\section{3. Effects of Initial Concentration of Hexavalent Chromium and Contact Time}

To understand the effects of initial concentration of the hexavalent chromium, $10-1000 \mathrm{mg} \mathrm{L}^{-1}$ initial concentrations were tested for the $25 \mathrm{~mL}$ total solution volume and $0.025 \mathrm{~g}$ of the biosorbent. The $q_{e}$ increased from 4.56 to $110.96 \mathrm{mg} \mathrm{g}^{-1}$ with increase in the initial hexavalent chromium concentration from 10 to $1000 \mathrm{mg} \mathrm{L}^{-1}$ at $25^{\circ} \mathrm{C}$. To identify the impact of temperature on the biosorption process, three different temperature values of 4,25 , and 45 ${ }^{\circ} \mathrm{C}$ were studied at both initial concentrations. The total volume of the hexavalent chromium solution and amount of biosorbent were $25 \mathrm{~mL}$ and $0.01 \mathrm{~g}$, respectively. As seen in Figure 3, when the temperature increases from 4 to 45 ${ }^{\circ} \mathrm{C}$, the $q_{e}$ increases from 1.33 to $11.26 \mathrm{mg} \mathrm{g}^{-1}$ at $10 \mathrm{mg}$ $\mathrm{L}^{-1}$ initial hexavalent chromium concentration. Figure 3 also depicts that the $q_{e}$ values at 4,25 , and $45^{\circ} \mathrm{C}$ are 87.67, 110.96 and $194.57 \mathrm{mg} \mathrm{g}^{-1}$, respectively.

To examine the effects of contact time, about 0.025 $\mathrm{g}$ of the biosorbent in $25 \mathrm{~mL}$ of the total solution volume with $100 \mathrm{mg} \mathrm{L}^{-1}$ hexavalent chromium solution was tested at 4,25 , and $45^{\circ} \mathrm{C}$ for $10-180 \mathrm{~min}$. At $4{ }^{\circ} \mathrm{C}, q_{e}$ increased

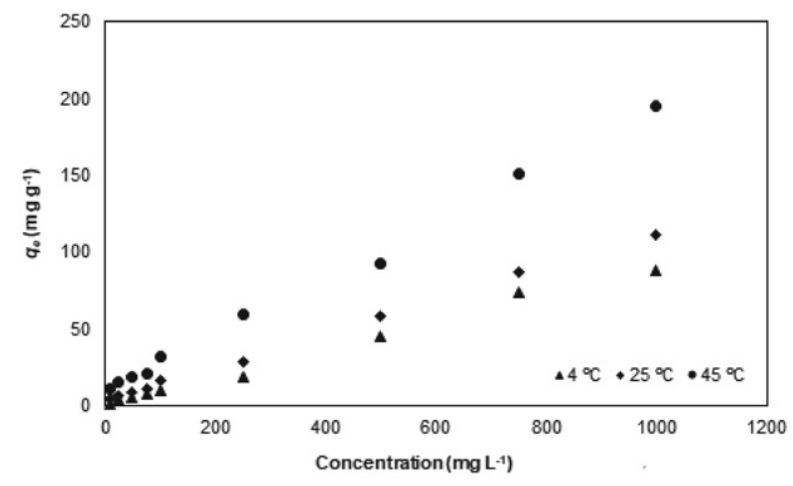

Figure 3. Effect of initial concentration of hexavalent chromium on its biosorption capacity $\left(q_{e}\right)$ onto the $L$. edodes biosorbent.

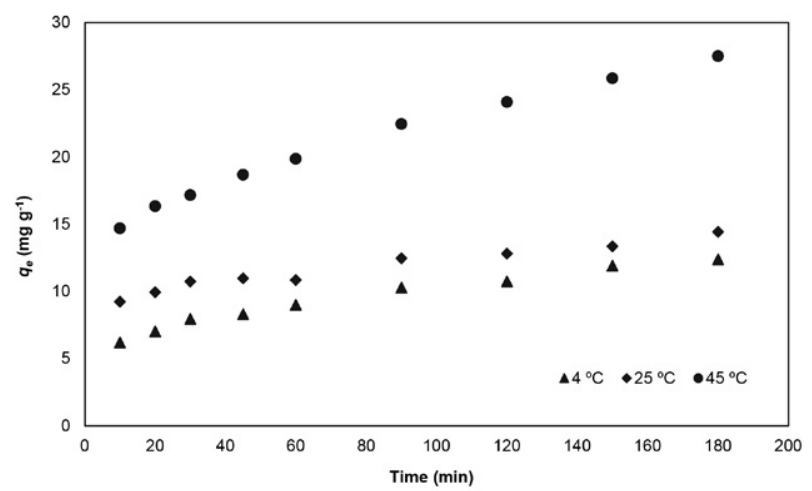

Figure 4. Effect of contact time on hexavalent chromium biosorption capacity $\left(q_{e}\right)$ onto the $L$. edodes biosorbent.

from 6.19 to $12.38 \mathrm{mg} \mathrm{g}^{-1}$, with temperature increase from 25 to $45^{\circ} \mathrm{C}, q_{e}$ increased from 14.42 to $27.48 \mathrm{mg} \mathrm{g}^{-1}$. These results are illustrated in Figure 4.

\section{4. Biosorption Isotherms}

To identify the interactions between the sorbate (liquid or gas) and sorbent, sorption isotherms were used. The Langmuir, Freundlich, and Sips isotherm models were investigated in this study. In the Langmuir isotherm model, the sorbate molecules interact with the sorbent molecules to form a monolayer, uniform and homogenous surface. In this model, all sorption sites are unique and morphologically homogeneous. The Langmuir equation can be expressed as follows:

$$
\frac{C_{e}}{q_{e}}=\frac{1}{Q_{L} K_{L}}+\frac{C_{e}}{Q_{L}}
$$

where $K_{L}$ is the Langmuir constant $\left(\mathrm{L} \mathrm{mg}^{-1}\right), C_{e}$ is the hexavalent chromium concentration under equilibrium (mg $\left.\mathrm{L}^{-1}\right), q_{e}$ is the amount of biosorbed hexavalent chromium $\left(\mathrm{mg} \mathrm{g}^{-1}\right.$ ) and $Q_{L}$ is the maximum Langmuir monolayer coverage capacity $\left(\mathrm{L} \mathrm{mg}^{-1}\right){ }^{21}$

The Freundlich isotherm model is suitable for heterogeneous surfaces and a reversible sorption process for multilayer sorbents. The Freundlich isotherm equality is given as follows:

$$
\ln q_{e}=\ln K_{F}+\frac{1}{n} \ln C_{e}
$$

Here, $K_{F}$ represents the Freundlich isotherm and $n$ is the biosorption intensity. The value of $1 / n$ characterizes the feasibility of the isotherm..$^{22}$ To investigate the applicability of the isotherm, a linear graph of $\ln q_{e}$ versus $\ln C_{e}$ was plotted, and the $K_{F}$ and $n$ values were calculated from the intercept and slope of the plot, respectively. ${ }^{23}$

The Sips isotherm equality is given as follows:

$$
\frac{1}{q_{e}}=\frac{1}{Q_{\max } K_{S}}\left(\frac{1}{c_{e}}\right)^{1 / n}+\frac{1}{Q_{\max }}
$$


where, $Q_{\max }$ is the maximum biosorption capacity ( $\mathrm{mg}$ $\left.\mathrm{g}^{-1}\right)$ and $K_{S}$ is the Sips constant $\left(\mathrm{L} \mathrm{mg}^{-1}\right)$.

The calculated data are given in Table 1 . As seen, the L. edodes fits better with the Freundlich model than the Langmuir or Sips models. The $K_{F}$ values were determined as $0.69,0.20$, and $0.19 \mathrm{~L} \mathrm{mg}^{-1}$ at 4,25 , and $45^{\circ} \mathrm{C}$, respectively. The $1 / n$ value gives the heterogeneity of the surface, ${ }^{24}$ so the $n$ values were calculated as $0.90,0.75$, and 0.65 at 4,25 , and $45^{\circ} \mathrm{C}$, respectively. $\mathrm{g}^{-1} \min ^{-1 / 2}$ ), and $t^{1 / 2}$ is the half-life time (s). Plots of the biosorbate uptake $q_{t}$ versus $t^{1 / 2}$ show a linear relationship when the IPD is rate limited.

The RSO model is expressed as follows: ${ }^{28}$

$\frac{1}{q_{t}}=\frac{1}{k_{R} q_{e} t}+\frac{1}{q_{e}}$

Here, $k_{R}$ is the RSO rate constant $\left(\mathrm{min}^{-1}\right), q_{e}$ and $q_{t}$ are the amounts of biosorbed hexavalent chromium at

Table 1. Biosorption isotherm constants for hexavalent chromium biosorption onto the $L$. edodes biosorbent.

\begin{tabular}{lccccccccc}
\hline & \multicolumn{2}{c}{ Langmuir Isotherm Constants } & \multicolumn{2}{c}{ Freundlich Isotherm Constants } & \multicolumn{2}{c}{ Sips Isotherm Constants } \\
\hline $\mathrm{T}(\mathrm{K})$ & $\begin{array}{c}K_{L} \times 10^{2} \\
\left(\mathrm{~L} \mathrm{mg}^{-1}\right)\end{array}$ & $\begin{array}{c}Q_{L} \\
\left(\mathrm{mg} \mathrm{g}^{-1}\right)\end{array}$ & $R^{2}$ & $\begin{array}{c}K_{F} \\
\left(\mathrm{~L} \mathrm{mg}^{-1}\right)\end{array}$ & $N$ & $R^{2}$ & $\begin{array}{c}K_{S} \times 10^{2} \\
\left(\mathrm{~L} \mathrm{mg}^{-1}\right)\end{array}$ & $\begin{array}{c}Q_{\max } \\
\left(\mathrm{mg} \mathrm{g}^{-1}\right)\end{array}$ \\
\hline 277 & 0.35 & 39.06 & 0.88 & 0.69 & 0.90 & 0.99 & 0.30 & 36.10 \\
298 & 3.43 & 14.68 & 0.95 & 0.20 & 0.75 & 0.97 & 2.84 & 11.55 \\
318 & 7.41 & 24.33 & 0.99 & 0.19 & 0.65 & 0.96 & 3.72 & 19.84 \\
\hline
\end{tabular}

\section{5. Biosorption Kinetics}

Kinetic analysis is important to clarify the transport mechanisms of biosorption, which have to be identified. Langergeren's first order (LFO), pseudo-second order (PSO), intraparticular diffusion (IPD), and Ritchie's second-order (RSO) kinetic models were thus calculated to identify the biosorption processes.

The LFO and PSO models are expressed as follows: 25,26

$$
\begin{aligned}
& \ln \left(q_{e}-q_{t}\right)=\ln q_{e}-k_{1} t \\
& \frac{t}{q_{t}}=\frac{1}{k_{2} q_{e}^{2}}+\frac{t}{q_{e}}
\end{aligned}
$$

Here, $q_{e}$ is the amount of biosorbed hexavalent chromium at equilibrium time $\left(\mathrm{mg} \mathrm{g}^{-1}\right), q_{t}$ is the amount of biosorbed hexavalent chromium at time $t$ ( $\mathrm{min})$, and $k_{1}$ $\left(\mathrm{min}^{-1}\right)$ and $k_{2}\left(\mathrm{~mol} \mathrm{~kg} \mathrm{~min}{ }^{-1}\right)$ are the LFO and PSO rate constants, respectively.

The IPD model represents the rate-limiting steps and is given as follows: ${ }^{27}$

$$
q_{t}=k_{i d} t^{1 / 2}
$$

where $q_{t}$ is the amount of biosorbed hexavalent chromium at time $t\left(\mathrm{~mol} \mathrm{~kg}^{-1}\right), k_{i d}$ is the IPD rate constant $(\mathrm{mg}$ equilibrium time $\left(\mathrm{mg} \mathrm{g}^{-1}\right)$ and at time $t(\mathrm{~min})$, respectively. In this model, the number of surface sites, $n$, are bounded by each biosorbate. The kinetic models are summarized at Table 2. According to the calculated values, the PSO kinetic model is suitable for the biosorption process. The $R^{2}$ values were 0.99 for all three temperatures $(4,25$, and 45 ${ }^{\circ} \mathrm{C}$ ), and the calculated $q_{e}$ values, which are similar to the experimental $q_{e}$ (Eq. 1) values, are 1.63, 4.27 , and $12.05 \mathrm{mg}$ $\mathrm{g}^{-1}$, respectively. Comparative results of the biosorption of $\mathrm{Cr}(\mathrm{VI})$ by various sorbents are given in Table 3 .

\section{6. Biosorption Thermodynamics}

The van't Hoff equation was used to calculate the thermodynamic parameters at different temperatures. The free energy change $\left(\Delta G^{o}\right)$, entropy change $\left(\Delta S^{\circ}\right)$, and enthalpy change $\left(\Delta H^{\circ}\right)$ values were determined as follows:

$$
\begin{aligned}
& \ln K_{L}=-\frac{\Delta H^{\circ}}{R T}+\frac{\Delta S^{\circ}}{R} \\
& \Delta G^{\circ}=\Delta H^{\circ}-T \Delta S^{\circ}
\end{aligned}
$$

\begin{tabular}{|c|c|c|c|c|c|c|c|c|c|c|c|c|}
\hline \multirow[b]{2}{*}{$T(\mathrm{~K})$} & \multicolumn{3}{|c|}{ LFO } & \multicolumn{3}{|c|}{ PSO } & \multicolumn{3}{|c|}{ IPD } & \multicolumn{3}{|c|}{ RSO } \\
\hline & $\begin{array}{c}q_{e} \exp \\
\left(\mathrm{mg} \mathrm{g}^{-1}\right)\end{array}$ & $\begin{array}{l}k_{1} \times 10^{2} \\
\left(\mathrm{~min}^{-1}\right)\end{array}$ & $\begin{array}{c}q_{e} \\
\left(\mathbf{m g} \mathbf{g}^{-1}\right)\end{array}$ & $R^{2}$ & $\begin{array}{r}k_{2} \times 10^{2} \\
(\mathrm{~mol} \mathrm{~kg} \mathrm{mi}\end{array}$ & $\begin{array}{c}q_{e} \\
\left(\mathrm{mg} \mathrm{g}^{-1}\right)\end{array}$ & $R^{2}$ & $\begin{array}{r}k_{i d} \\
\left(\mathrm{mg} \mathrm{g}^{-1} \mathrm{mi}\right.\end{array}$ & $R^{2}$ & $\begin{array}{c}k_{R} \\
\left(\mathrm{~min}^{-1}\right)\end{array}$ & $\begin{array}{c}q_{e q} \\
\left(\mathbf{m g} \mathbf{g}^{-1}\right)\end{array}$ & $R^{2}$ \\
\hline 277 & 1.32 & 1.60 & 2.08 & 0.93 & 7.49 & 1.63 & 0.99 & 0.60 & 0.99 & 4.37 & 6.02 & 0.85 \\
\hline 298 & 4.56 & 1.72 & 2.07 & 0.66 & 7.01 & 4.27 & 0.99 & 0.42 & 0.88 & 8.06 & 4.23 & 0.55 \\
\hline 318 & 11.26 & 1.38 & 2.76 & 0.98 & 3.42 & 12.05 & 0.99 & 1.25 & 0.99 & 10.49 & 12.50 & 0.79 \\
\hline
\end{tabular}

where $T$ represents the absolute temperature $(\mathrm{K}), R$ is the universal gas constant $\left(8.314 \mathrm{~J} \mathrm{~mol}^{-1} \mathrm{~K}^{-1}\right)$, and $K_{L}$ is the Langmuir equilibrium constant.

Table 2. Biosorption kinetic models and parameters for hexavalent chromium biosorption onto the L. edodes biosorbent. 
Table 3. Biosorption of $\mathrm{Cr}(\mathrm{VI})$ by different sorbents.

\begin{tabular}{|c|c|c|c|c|c|c|c|}
\hline Sorbent & $\begin{array}{l}\text { Sorption } \\
\text { capacity }\end{array}$ & pH & Time & $\mathbf{T}(\mathbf{K})$ & $\begin{array}{l}\text { Isotherm } \\
\text { model }\end{array}$ & $\begin{array}{l}\text { Kinetic } \\
\text { model }\end{array}$ & Reference \\
\hline Arthrobacter viscosus & $14.4 \mathrm{mg} / \mathrm{g}$ & 2 & $144 \mathrm{~h}$ & 299 & Langmuir & - & 29 \\
\hline Spirulina sp. & $59.57 \mathrm{mg} / \mathrm{g}$ & 5 & $60 \mathrm{~min}$ & 298 & $\begin{array}{l}\text { Langmuir } \\
\text { and Freundlich }\end{array}$ & PSO & 30 \\
\hline Agaricus campestris & $56.21 \mathrm{mg} / \mathrm{g}$ & 2 & $60 \mathrm{~min}$ & 318 & Langmuir & PSO & 9 \\
\hline $\begin{array}{l}\text { Multi-shell hollow } \\
\text { micro-meso-macroporous silica }\end{array}$ & $257.67 \mathrm{mg} / \mathrm{g}$ & 4 & $90 \mathrm{~min}$ & 293 & Langmuir & - & 31 \\
\hline Activated carbon & $54.8 \mathrm{mg} / \mathrm{g}$ & 3.5 & $72 \mathrm{~h}$ & 333 & Langmuir & PSO & 32 \\
\hline Cellulose hydrogel coating with $\mathrm{Fe}^{0}$ & $98.2 \%$ & 5 & $4 \mathrm{~h}$ & 313 & - & LFO & 33 \\
\hline Sugarcane bagasse & $87 \%$ & 6.7 & $100 \mathrm{~min}$ & 319 & $\begin{array}{l}\text { Redlich-Peterson } \\
\text { and Temkin }\end{array}$ & LFO & 34 \\
\hline Lentinula edodes & $194,57 \mathrm{mg} \mathrm{g}^{-1}$ & 2 & 3 ure & 318 & Freundlich & PSO & This study \\
\hline
\end{tabular}

Positive or negative values of $\Delta G^{o}$ indicate the spontaneity or non-spontaneity of the biosorption process, $\Delta H^{\circ}$ supplies information about the process and whether it is exothermic or endothermic. ${ }^{35}$ Finally, another thermodynamic parameter, $\Delta S^{o}$, gives information about the randomness of the biosorption process. The thermodynamic parameters were calculated using Eq. 14, and these data are given in Table 4. It is observed that biosorption is an exothermic process $\left(\Delta H^{o}=-4.587 \mathrm{~kJ} \mathrm{~mol}^{-1}\right)$ and that the randomness decreases during the process $\left(\Delta S^{o}=-0.738 \mathrm{~J} \mathrm{~mol}^{-1}\right.$ $\left.\mathrm{K}^{-1}\right)$. The calculated $\Delta G^{o}$ values were $3.61,3.36$, and $3.14 \mathrm{~kJ}$ $\mathrm{mol}^{-1}$ at 4,25 , and $45^{\circ} \mathrm{C}$, respectively. These results indicate that $\Delta G^{o}$ decreases with increasing temperature and that the biosorption process is suitable for high temperatures.

Table 4. Thermodynamic parameters for hexavalent chromium biosorption onto the L. edodes biosorbent.

\begin{tabular}{lccc}
\hline$\Delta H^{o}\left(\mathrm{~kJ} \mathrm{~mol}^{-1}\right)$ & & -4.587 & \\
$\Delta S^{o}\left(\mathrm{~J} \mathrm{~mol}^{-1} \mathrm{~K}^{-\mathbf{1}}\right)$ & & -0.738 & \\
& $\mathbf{2 7 7} \mathrm{K}$ & $\mathbf{2 9 8 \mathrm { K }}$ & $\mathbf{3 1 8 \mathrm { K }}$ \\
$\Delta \mathbf{G}^{\boldsymbol{o}}\left(\mathrm{kJ} \mathrm{mol}^{-\mathbf{1}}\right)$ & 3.61 & 3.36 & 3.14 \\
\hline
\end{tabular}

\section{7. Desorption and Reusability of the Biosorbent}

Approximately $0.1 \mathrm{~mol} \mathrm{~L}^{-1} \mathrm{HCl}$ and $0.1 \mathrm{~mol} \mathrm{~L}^{-1}$ of $\mathrm{HNO}_{3}$ were used as the desorption agents, and based on the results, the $0.1 \mathrm{~mol} \mathrm{~L}^{-1}$ concentration of $\mathrm{HNO}_{3}$ (96.37\%) was more effective than $0.1 \mathrm{~mol} \mathrm{~L}^{-1}$ of $\mathrm{HCl}$ (35.89\%). To determine the reusability of the L. edodes as a biosorbent, the biosorption-desorption cycles were repeated five times, during which the biosorption capacity decreased by $7 \%$.

\section{8. Characterization of the Biosorbent}

The effective functional groups of the L. edodes biosorbent for hexavalent chromium biosorption were ex- amined using FTIR spectroscopy. The FTIR spectra of the biosorbent before and after biosorption in the range of $4000-600 \mathrm{~cm}^{-1}$ are given in Figure 5. The strong and broad bands at 3267 and $3260 \mathrm{~cm}^{-1}$ are attributed to the $-\mathrm{OH}$ and -NH groups before and after biosorption, respectively. The peak at $2922 \mathrm{~cm}^{-1}$ are attributed to $\mathrm{C}-\mathrm{H}$ stretching, and the peaks observed at $1628-1634 \mathrm{~cm}^{-1}$ correspond to carboxylate functional groups and carboxyl groups of the biosorbent. Stretching of the -COO group is represented at $1371-1364 \mathrm{~cm}^{-1}$, and the peaks at $1017-1019 \mathrm{~cm}^{-1}$ are assigned to $\mathrm{N}-\mathrm{H}$ or $\mathrm{C}-\mathrm{O}$ band absorption.
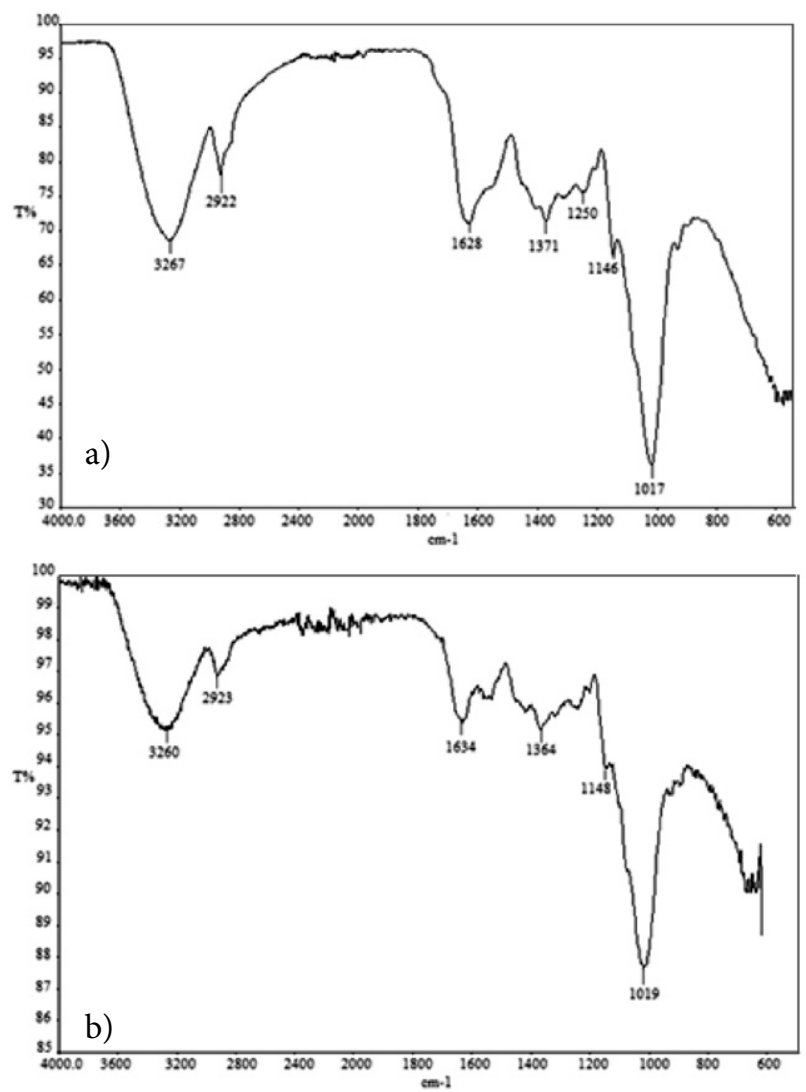

Figure 5. FTIR spectra of the L. edodes biosorbent (a) before and (b) after biosorption of hexavalent chromium. 

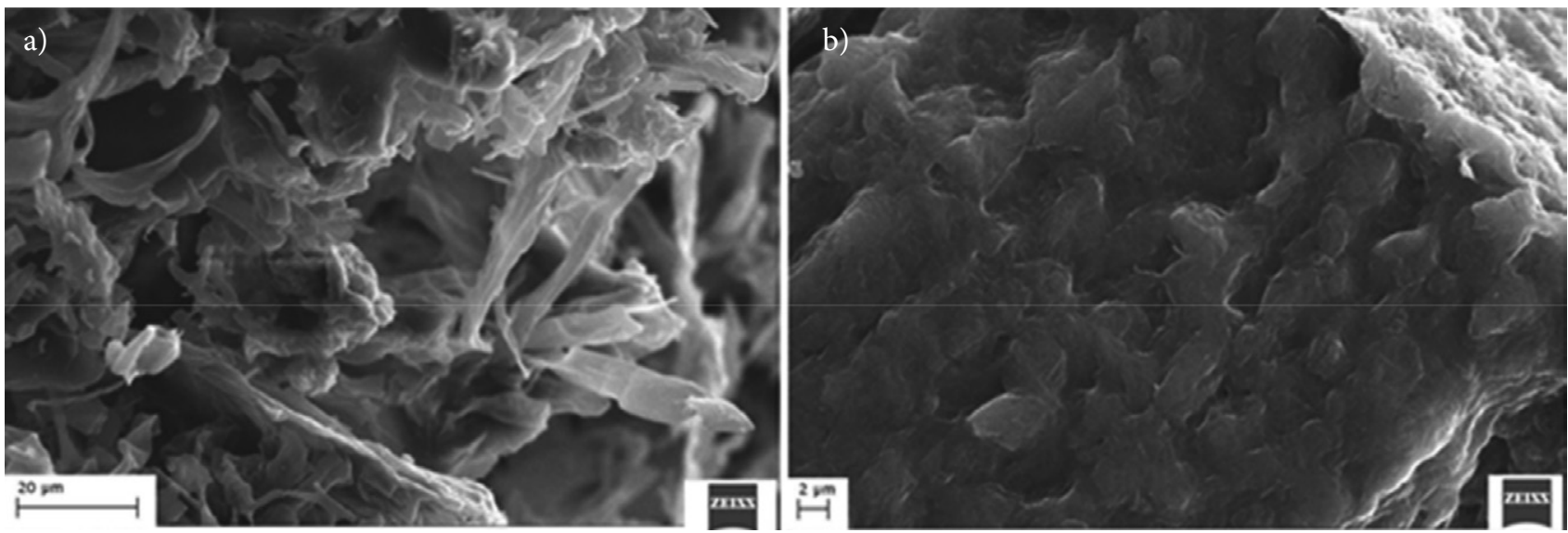

Figure 6. SEM images of the L. edodes biosorbent (a) before and (b) after biosorption of hexavalent chromium.

To identify the surface morphology of the biosorbent SEM was used. As seen in Figure 6, the surface of the biomass has some heterogeneity and becomes smoother after biosorption owing to binding of the hexavalent chromium ions to the functional sites of the biosorbent.

\section{Conclusion}

The main aim of this study was to examine the viability of $L$. edodes as a biosorbent for hexavalent chromium biosorption. In this assessment, the optimum biosorption parameters such as $\mathrm{pH}$, temperature, biosorbent dosage, and contact time, were determined. The optimum process parameters were detected as $\mathrm{pH}$ of 2.0 , total biosorbent dosage of $0.025 \mathrm{~g}$, and maximum biosorption capacity of $194.57 \mathrm{mg} \mathrm{g}^{-1}$ during $3 \mathrm{~h}$ of biosorption at $45^{\circ} \mathrm{C}$. The obtained data were applied to certain physicochemical parameters, such as isotherm, thermodynamic, and kinetic models, to identify the biosorption process. The Freundlich isotherm and PSO kinetic models were found to be suitable for the biosorption process and observed to fit well with the experimental data. The standard enthalpy and standard entropy were calculated as $-4.587 \mathrm{~kJ} \mathrm{~mol}^{-1}$ and $-0.738 \mathrm{~J} \mathrm{~mol}^{-1} \mathrm{~K}^{-1}$, respectively. In addition, the $L$. edodes biosorbent was determined to be an effective and a renewable biomaterial that was suitable for hexavalent chromium biosorption from aqueous solutions, this biosorbent showed high sorption capacity for treatment of wastewater contaminated with hexavalent chromium.

\section{References}

1. J. R. M. B. Smily, P. A. Sumithra, HAYATI J. Biosci. 2017, 24(2), 65-71. DOI:10.1016/j.hjb.2017.08.005

2. J. Wang, Q. Xie, A. Li, X. Liu, F. Yu, J. Ji, Water Sci. Technol. 2020, 81(6), 1114-1129. DOI:10.2166/wst.2020.167

3. N. K. Mondal, A. Samanta, S. Dutta, S. Chattoraj, J. Genet. Eng. Biotechnol. 2017, 15(1), 151-160.
DOI:10.1016/j.jgeb.2017.01.006

4. J. J. Pan, J. Jiang, R. K. Xu, Chemosphere, 2014, 101, 71-76. DOI:10.1016/j.chemosphere.2013.12.026

5. Y. Li, Y. Wei, S. Huang, X. Liu, Z. Jin, M. Zhang, J. Qu, Y. Jin, J. Mol. Liq. 2018, 269, 824-832.

DOI:10.1016/j.molliq.2018.08.060

6. Z. Shi, S. Peng, X. Lin, Y. Liang, S. -Z. Lee, H. E. Allen, Environ. Sci. Process. Impacts. 2020, 22, 95-104.

DOI:10.1039/C9EM00477G

7. E. Nakkeeran, C. Patra, T. Shahnaz, S. Rangabhashiyam, N. Selvaraju, Bioresour. Technol. Reports. 2018, 3, 256-260.

DOI:10.1016/j.biteb.2018.09.001

8. R. Xiao, J. J. Wang, R. Li, J. Park, Y. Meng, B. Zhou, S. Pensky, Z. Zhang, Chemosphere., 2018, 208, 408-416.

DOI:10.1016/j.chemosphere.2018.05.175

9. A. Göçenoğlu Sarıkaya, Environ. Technol. 2021, 42(1), 72-80. DOI:10.1080/09593330.2019.1620867

10. S. H. Abbas, Y. M. Younis, M. K. Hussain, F. H. Kamar, G. Nechifor, B. Pasca, Rev. Chim. 2020, 71(1), 1-12.

DOI:10.37358/RC.20.1.7804

11. C. Patra, T. Shahnaz, S. Subbiah, S. Narayanasamy, Environ. Sci. Pollut. Res. 2020, 27, 14836-14851.

DOI:10.1007/s11356-020-07979-y

12. A. K. Prajapati, S. Das, M. K. Mondal, J. Mol. Liq. 2020, 307, 112956. DOI:10.1016/j.molliq.2020.112956

13. V. Kalola, C. Desai, Environ. Sci. Pollut. Res. 2019 DOI:10.1007/s11356-019-05942-0

14. A. De Rossi, M. R. Rigon, M. Zaparoli, R. D. Braido, L. M. Colla, G. L. Dotto, J. S. Piccin, Environ. Sci. Pollut. Res. 2018 , 25(19), 19179-19186. DOI:10.1007/s11356-018-2377-4

15. P. S. Bisen, R. K. Baghel, B. S. Sanodiya, G. S. Thakur, G. B. Prasad, Curr. Med. Chem. 2010, 17(22), 2419-2430. DOI:10.2174/092986710791698495

16. T. Chen, Z. Zhou, S. Xu, H. Wang, W. Lu, Bioresour. Technol. 2015, 190, 388-394. DOI:10.1016/j.biortech.2015.04.115

17. P. Miretzky, A. Cirelli, J. Hazard. Mater. 2010, 180(1-3), 1-19. DOI:10.1016/j.jhazmat.2010.04.060

18. S. Sugashini, K. M. M. S. Begum, Clean. Technol. Environ. Policy. 2013, 15, 293-302. DOI:10.1007/s10098-012-0512-3

19. Z. Aksu, U. Açikel, E. Kabasakal, S. Tezer, Water Res. 2002, 
36(12), 3063-3073. DOI:10.1016/S0043-1354(01)00530-9

20. Z. K. Wang, C. L. Ye, X. Y. Wang, J. Li, Appl. Surf. Sci. 2013, 287, 232-241. DOI:10.1016/j.apsusc.2013.09.133

21. I. Langmuir, J. Am. Chem. Soc. 1918, 40(9), 1361-143. DOI:10.1021/ja02242a004

22. E. Radu, E. E. Oprescu, C. E. Enascuta, C. Calin, R. Stoica, G. V. Scaeteanu, G. Vasilievici, L. Capra, G. Ivan, A. C. Ion, Rev. Chim. 2018, 69(1), 191-195. DOI:10.37358/RC.18.1.6072

23. H. Freundlich, J. Phys. Chem. A. 1906, 57, 385-471.

24. Y. Özüdoğru, M. Merdivan, Trak. Univ. J. Nat. Sci. 2017, 18(2), 81-87. DOI:10.23902/trkjnat.300344

25. S. Lagergren, Sven. Vetenskapsakad Handingarl, 1898, 24, $1-39$.

26. S. K. Srivastava, V. K. Gupta, S. Anurpam, D. Mohan, Indian J. Chem. 1995, 34A, 342-350.

27. T. Furusawa, J. M. Smith, AlChE Journal, 1974, 20, 88. DOI:10.1002/aic.690200111

28. A. G. Ritchie, J. Chem. Soc. Faraday Trans. 1977, 73, 1650. DOI:10.1039/f19777301650
29. R. M. Hlihor, H. Figueiredo, T. Tavares, M. Gavrilescu, Process. Saf. Environ. 2017, 108, 44-56.

DOI:10.1016/j.psep.2016.06.016

30. H. Rezaei, Arab. J. Chem. 2016, 9, 846-853. DOI:10.1016/j.arabjc.2013.11.008

31. R. Soltani, A. Marjani, R. Soltani, S. Shirazian, Sci. Rep. 2020,10, 9788. DOI:10.1038/s41598-020-66540-6

32. Y. Wang, C. Peng, E. Padilla-Ortega, A. Robledo-Cabrera, A. Lopez-Valdivieso, J. Environ. Chem. Eng. 2020, 8(4), 104031. DOI:10.1016/j.jece.2020.104031

33. Y. Wang, L. Yu, R. Wang, Y. Wang, X Zhang, Sci. Total Environ. 2020, 726, 138625. DOI:10.1016/j.scitotenv.2020.138625

34. R. R. Karri, J. N. Sahu, B. C. Meikap, Industrial Crops and Products, 2020, 143, 111927. DOI:10.1016/j.indcrop.2019.111927

35. R. M. Senin, I. Ion, O. Oprea, R. Stoica, R. Ganea, A. C. Ion, Rev. Chim. 2018, 69(5), 1233-1239. DOI:10.37358/RC.18.5.6297

\section{Povzetek}

Namen študije je bil preučitev sposobnosti adsorpcije kroma (VI) z glivo šitake (Lentinula edodes). Da bi določili optimalne pogoje smo spreminjali pH vrednost raztopine kroma (VI), količino šitake, temperaturo, kontaktni čas in koncentracijo kroma (VI). Adsorpcijski mehanizem smo opisali z izotermičnimi, kinetičnimi in termodinamskimi parametri. Funkcionalne skupine in morfologijo površine glive smo analizirali s FTIR in SEM v odsotnosti in prisotnosti kroma (VI). Maksimalna adsorpcijska kapaciteta je znašala $194.57 \mathrm{mg} \mathrm{g}^{-1}$, pod kislimi pogoji pri temperaturi $45^{\circ} \mathrm{C}$. Na osnovi kinetičnih študij smo zaključili, da lahko ravnotežje opišemo s Freundlichovo izotermo, adsorpcijo pa s kinetičnim modelom psevdo-prvega reda. Visoka adsorpcijska sposobnost $L$. edodes kaže potencial njene uporabe za čiščenje odpadnih vod.

Except when otherwise noted, articles in this journal are published under the terms and conditions of the Creative Commons Attribution 4.0 International License 